\title{
Development of probiotic dairy beverages: Rheological properties and application of mathematical models in sensory evaluation
}

\author{
W. F. Castro,, ${ }^{* 1}$ A. G. Cruz, ${ }^{*}$ M. S. Bisinotto, ${ }^{*}$ L. M. R. Guerreiro, ${ }^{*}$ J. A. F. Faria, ${ }^{*}$ H. M. A. Bolini, ${ }^{*}$ R. L. Cunha, ${ }^{*}$ \\ and R. Deliza† \\ *Universidade Estadual de Campinas (UNICAMP), Faculdade de Engenharia de Alimentos (FEA), Cidade Universitária Zeferino Vaz, \\ 13083-862 Campinas, SP, Brazil \\ †Empresa Brasileira de Pesquisa Agropecuária, Embrapa Agroindústria de Alimentos, Av. das Américas, 29501 Guaratiba, \\ 23020-470 Rio de Janeiro, RJ, Brazil
}

\begin{abstract}
Strawberry-flavored probiotic dairy beverages $(2 \%$ $\mathrm{vol} / \mathrm{vol}$ Lactobacillus acidophilus) were produced using $0,20,35,50,65$, and $80 \%$ (vol/vol) whey in their formulations. Mathematical models (survival analysis, minimal significant difference, and mean global acceptance) were used to identify the optimal (sensorially) whey concentration in probiotic beverages. Fifty-five consumers evaluated acceptance of the beverages using hybrid 9-point hedonic scales. In addition, Lb. acidophilus were enumerated and $\mathrm{pH}$ was determined. Rheological behavior is an important characteristic for the processing and sensory acceptance of dairy beverages, varying with the presence of additives, fermentation process (time, bacterial strain), and whey concentrations used. All beverages presented minimal counts of $8 \mathrm{log} \mathrm{cfu} / \mathrm{mL}$ of $\mathrm{Lb}$. acidophilus, and $\mathrm{pH}$ ranged from 4.09 to 4.14. Increasing the whey content increased the fragility of the gel structure, probably because of the replacement of casein by whey proteins, once the concentrations of other ingredients in formulation were fixed. Whey content had a significant effect on acceptance of the probiotic dairy beverages; beverages with whey contents greater than $65 \%$ resulted in lower acceptance by consumers. The model of mean global acceptance presented 2 solutions with high sensory scores: beverages with 12 and $65 \%$ whey, the latter being of interest because it allows greater use of the whey by-product. The Weibull distribution presented a prediction of whey concentration of $49 \%$, with higher sensory acceptance. The methodologies used in this research were shown to be useful in determining the constituents of food formulations, especially for wheybased probiotic beverages.
\end{abstract}

Key words: mathematical model, probiotic, rheological property, whey beverage

Received April 2, 2012.

Accepted July 29, 2012.

${ }^{1}$ Corresponding author: wellfreitas@gmail.com

\section{INTRODUCTION}

Dairy beverages are produced from milk or its derivatives, with or without the addition of other ingredients, in which the dairy base represents at least $51 \%$ (vol/ vol) of the formulation, and can be submitted to a fermentation process using yogurt cultures (Brazil, 2005). In 2010, Brazil imported US\$39 million in whey and exported US $\$ 8,145$ (Brazil, 2012). The data show a high demand for cheese whey, because Brazilian consumption of whey-based foods and beverages is also high. The consumption of dairy beverages is mainly associated with the consumption of yogurt, due to their similar sensory properties and the healthy habits of consumers (Zhu et al., 2009).

From the technological viewpoint, the main difference between yogurt and fermented dairy beverages is the addition of whey to the latter, which results in lower viscosity. The physical characteristics of dairy products may be affected by factors such as composition and heat treatment of milk, breaking of the gel, the use of stabilizers, the microbial culture used (Nielsen, 1975; Parnell-Clunies et al., 1986; Hassan et al., 1996), and the storage conditions until the end of shelf life (Marafon et al., 2011).

Supplementation with probiotic bacteria and prebiotic ingredients represents a new option to add further value to dairy beverages, as reported in various studies on their adequacies as a food matrix (Oliveira et al., 2002; Castro et al., 2009; Zoellner et al., 2009) and on their health benefits, such as a decrease in blood pressure (Fluegel et al., 2010).

One of the main objectives of the food industry is to manufacture products with good sensory acceptance. To attain this objective and overcome strong competition within the sector, products must meet the expectations of the consumer. In this context, the use of whey in the production of dairy beverages could be a promising alternative for dairy industries, because dairy beverages are viewed positively by consumers (Krešić et al., 2010). The intrinsic human-health ben- 
efits of cheese whey are well known and include the prevention of cancer, increase in levels of glutathione, increase in antimicrobial function, and an increase in the satiety response (Madureira et al., 2007). Increased amounts of whey in dairy products imply greater use of this valuable industrial by-product, with a beneficial environmental impact. In addition, it could contribute to a re-evaluation of current Brazilian legislation, based on the acceptance of dairy beverages with higher levels of whey by consumers. The whey level is not specified by Brazilian legislation for whey beverages. Cruz et al. (2010) concluded, based on consumer acceptance tests, that the shelf life of probiotic yogurts was generally greater than that presented on the label. In a recent review paper, Hough and Garitta (2012) approached the use of survival analysis as mathematical methodology to estimate shelf life of foods by correlation with sensory data.

However, information is still lacking on the most suitable level of whey that can be added to a formulation and result in adequate acceptance by consumers. For a product containing whey as a basic ingredient, this information is essential. In this context, our research aimed to evaluate the rheological properties in probiotic dairy beverages with increased whey content and to identify adequate levels of whey in the formulation, based on consumer data, by mathematical models. Three mathematical methodologies were used: survival analysis, mean global acceptance, and minimal significant difference.

\section{MATERIALS AND METHODS}

\section{Processing of the Probiotic Beverage Formulations}

Pasteurized milk (3\% fat, Líder, Lobato, Brazil) and cheese whey, which was obtained during the production of Minas fresh cheese by the enzymatic coagulation process before the salting step ( $\mathrm{pH} 6.26$, total solids $7.12 \%$ $\mathrm{wt} / \mathrm{wt}$ ), were used to formulate the probiotic beverages. The inoculum was prepared using reconstituted (11\% wt/vol) skim milk powder (Molico, São Paulo, Brazil), Streptococcus salivarius ssp. thermophilus (TA-40, DuPont, Copenhagen, Denmark), Lactobacillus delbrueckii ssp. bulgaricus (LB-340, DuPont), and a probiotic culture of Lactobacillus acidophilus LA-14 (DuPont). Sugar and a strawberry-flavored fruit preparation containing strawberry pulp and a natural dye (Duas Rodas Company, Jaraguá do Sul, SC, Brazil) were also added.

Six beverages were formulated, containing 0 (control), 20, 35, 50, 65, and $80 \%$ ( vol/vol) whey, with the remaining volume made up with milk. Preliminary experiments indicated that these whey concentrations were appropriate for sensory tests. Sugar was added to the probiotic beverage at a concentration of $10 \%$ (wt/ vol) and the mixtures were heat-treated at $83^{\circ} \mathrm{C}$ for 15 min. After cooling the mixtures to $46^{\circ} \mathrm{C}$, the fruit preparation was added at $1 \%$ (wt/vol), the starter culture inoculum at $1 \%$, and the probiotic culture inoculum at $2 \%(\mathrm{vol} / \mathrm{vol})$. The mixture was kept at $45^{\circ} \mathrm{C}$ for the fermentation process, which was stopped by cooling to $8^{\circ} \mathrm{C}$ when the $\mathrm{pH}$ value reached 4.7 . The beverages were stored under refrigeration until the consumer test.

\section{Physicochemical and Microbiological Analyses}

The $\mathrm{pH}$ values of the raw materials (milk and whey) and of the samples were determined using a Digimed $\mathrm{pH}$ meter (DM-20, Digimed, São Paulo, Brazil) equipped with an electrode and thermo-compensator (Marshall, 1993). The enumeration of $L b$. acidophilus was carried out in duplicate using de Man, Rogosa, and Sharpe agar supplemented with $0.15 \%$ (wt/vol) of bile salts (Oxoid, São Paulo, Brazil), incubating anaerobically for $3 \mathrm{~d}$ at $37^{\circ} \mathrm{C}$ (Mortazavian et al., 2007).

\section{Rheological Analyses}

The rheological parameters were determined using a controlled stress rate rheometer (model 1500 AR ex, TA Instruments, New Castle, DE) equipped with cone-plate geometry. The temperature of the system was set and maintained at $25^{\circ} \mathrm{C}$ for the flow curve and mechanical spectrum analyses. All measurements were performed in triplicate samples.

The flow curves of the whey-based probiotic beverages were determined using shear rate ranging from 0 to $300 \mathrm{~s}^{-1}$. The dairy beverages were submitted to 3 shear-rate sweeps (up-down-up) in order to eliminate thixotropy, and the rising curves (1 and 3) were adjusted to the power-law model (Equation [1]):

$$
\sigma=k(\dot{\gamma})^{n}
$$

where $\sigma$ is the shear stress $(\mathrm{Pa}), k$ is the consistency index $\left(\mathrm{Pa} \cdot \mathrm{s}^{\mathrm{n}}\right), \dot{\gamma}$ is the strain rate $\left(\mathrm{s}^{-1}\right)$, and $n$ is the flow index.

The oscillatory measurements were performed with $1 \%$ maximum strain, and the frequency varied from 0.01 to $10 \mathrm{~Hz}$. From dynamic rheological tests in the linear viscoelastic range, the storage (or elastic) modulus $\left(\mathbf{G}^{\prime}\right)$, the loss (or viscous) modulus $\left(\mathbf{G}^{\prime \prime}\right)$, and the loss factor $\left(\tan \delta ; G^{\prime \prime} / G^{\prime}\right)$ can be obtained. The $G^{\prime}$ value is a measure of the deformation energy stored in the sample during the shear process, representing the elastic behavior of a sample. In contrast, the $\mathrm{G}^{\prime \prime}$ value is a measure of the deformation energy used up in the 
sample during shear and lost to the sample afterward, representing the viscous behavior of a sample. Previous studies relate the calculation of these parameters for functional dairy foods processing (Debon et al., 2010, 2012; Marafon et al., 2011; Pinto et al., 2012).

\section{Consumer Test}

Fifty-five consumers (Hough et al., 2007) of fermented dairy products were randomly selected and invited to take part in the test. The samples were presented monadically at $5 \pm 1^{\circ} \mathrm{C}$, served in polystyrene cups coded with 3-digit numbers, following the sample presentation design in balanced complete blocks (MacFie et al., 1989) aimed at decreasing the carryover and first-order effects. The samples were presented in individual booths illuminated with white light under controlled humidity and temperature $\left(23^{\circ} \mathrm{C}\right)$, serving $30-\mathrm{mL}$ samples to each consumer. Participants were instructed to eat a cream cracker and drink water between samples to cleanse the palate. They evaluated the samples acceptance using a 9-point hybrid hedonic scale (Drake, 2007), where $1=$ disliked extremely, and $9=$ liked extremely. Panelists were also asked whether they would normally consume the product, answering with yes or no. The consumer test was carried out after samples had undergone $15 \mathrm{~d}$ of refrigerated storage, corresponding to half the normal commercial shelf life of such products $(30 \mathrm{~d})$.

\section{Mathematical Modeling}

Mean Global Acceptance. The model expressing mean global acceptance was obtained from the mean acceptance scores provided by the 55 consumers for the evaluated samples. The data were inserted on the axis of the $x-y$ coordinates, $y$ being the function representing the mean score of the judges as a function of the whey content of the sample $(x)$. They were subsequently modeled using a second-order polynomial equation

$$
y=\beta_{11} x^{2}+\beta_{22} x+\beta_{0},
$$

where $\beta=$ coefficients of the quadratic equation.

Minimal Significant Difference. The maximum percentage of cheese whey that could be used in the formulation of the probiotic beverage can be estimated from the percentage of consumers who were aware of the first significant difference in sensory characteristics of the product under evaluation compared with the sample without cheese whey. The first significant difference perceived by consumers with respect to the cheese whey content can be calculated using Equation [2] (Hough et al., 2002; Ares et al., 2009):

$$
S=F-Z_{\alpha} \sqrt{\frac{2 \times M S E}{n}},
$$

where $S=$ the first significant difference in the acceptance of the product containing cheese whey; $F=$ the acceptance of the control sample; $Z_{\alpha}=$ uni-caudal coordinate of the normal curve at the $\alpha$ level of significance; $M S E=$ mean square of the error derived from the ANOVA of the consumer data; and $n=$ number of consumers.

Survival Analysis. For definition purposes, one can consider any variable $c$ (e.g., whey concentration) that is capable of causing rejection of the sample. The function $F(c)$ or rejection function (Hough et al., 2003) is defined as the probability $(P)$ of the consumer (or group of consumers) rejecting the product with a whey concentration $(C)$ less than $c$, and is mathematically expressed as $F(c)=P(C<c)$. The Weibull distribution (Equation [3]) used in this study has been applied in various studies involving the determination of the sensory shelf life of processed foods, such as ricotta cheese (Hough et al., 1999), ready-to-eat lettuce (Araneda et al., 2008), alfajor (Gámbaro et al., 2004), and high hydrostatic pressure-processed avocado and mango pulps (Jacobo-Velázquez et al., 2010):

$$
F(c)=1-S_{\text {sev }}\left(\frac{\ln (c)-\mu}{\sigma}\right),
$$

where $S_{\text {sev }}(\cdot)$ is the survival function for the lowest value of the distribution $S_{s e v}(w)=\exp \left(-\mathrm{e}^{\mathrm{w}}\right)$, and $\mu$ and $\sigma$ are model parameters.

The responses of the judges were coded 1 for the response "no" and 0 for the response "yes" in response to the question "would you normally consume this product?" The data were inserted into SAS software (version 9.2, SAS Institute Inc., Cary, NC) to carry out the survival analysis.

\section{Statistical Analysis}

The data were submitted to one-way ANOVA (with sample as fixed factor) with a subsequent comparison of the means by Tukey's test.

\section{RESULTS AND DISCUSSION}

\section{pH and Microbiological Values}

In addition to enumeration of $L b$. acidophilus, all samples were subjected to counts of yeasts and molds and coliforms to evaluate the hygienic or sanitary con- 
ditions of the process. Based on the results, we concluded that the beverages met the standards for human consumption according to the Brazilian legislation, thus allowing their use in sensory tests.

Table 1 shows the $\mathrm{pH}$ values and Lb. acidophilus counts in whey probiotic beverages. The $\mathrm{pH}$ values varied from 4.09 to 4.14, suggesting the occurrence of post-acidification during storage, a phenomenon normally found in fermented dairy products. With respect to $L b$. acidophilus count, all beverages presented values $>8 \log \mathrm{cfu} / \mathrm{mL}$, indicating a probiotic level sufficient to provide consumer benefits and to compensate a possible reduction caused by passage through the gastrointestinal tract (Granato et al., 2010). In accordance with Brazilian legislation, the whey drinks showed probiotic counts $>10 \mathrm{cfu} / 100 \mathrm{~mL}$ of product. The whey content did not interfere in the viability of probiotics in the dairy beverages $(P>0.05)$, indicating no limit in the capacity of the probiotic strain to metabolize the peptides present in the whey. These results confirmed the technological application of fresh whey from Minas Frescal cheese as a means to develop probiotic bacteria (Almeida et al., 2008, 2009). Moreover, our findings were comparable to those of other studies involving dairy beverages (Madureira et al., 2010) and to results obtained for other dairy products processed from cheese whey (Madureira et al., 2005, 2008, 2011a,b) and other dairy foods, such as yogurts (Cruz et al., 2012), cheese (Gomes et al., 2011; Escobar et al., 2012), and ice cream (Di Criscio et al., 2010; Ferraz et al., 2012).

Our results emphasize the potential of the whey beverage as an adequate food matrix for the supplementation with probiotic bacteria, a topic relevant to the development of probiotic dairy foods (Ranadheera et al., 2010). A whey beverage portion size of $200 \mathrm{~mL}$ is established in Brazil (Brazil, 2003), and Brazilian legislation establishes a minimum probiotic viable count of 8 to $9 \log \mathrm{cfu} / \mathrm{g}$ or $\mathrm{cfu} / \mathrm{mL}$ in processed foods (Brazil, 2008); our findings indicate probiotic counts ranging from 10.13 to $10.99 \log \mathrm{cfu} / 200 \mathrm{~mL}$ of whey beverage. This value is comparable to those present in commercial

Table 1. $\mathrm{pH}$ values and probiotic microbial counts $(\log \mathrm{cfu} / \mathrm{mL}$; means $\pm \mathrm{SD}$ ) of probiotic dairy beverages with different whey contents

\begin{tabular}{llc}
\hline $\begin{array}{l}\text { Formulation } \\
\text { (\% whey) }\end{array}$ & $\mathrm{pH}$ & $\begin{array}{c}\text { Lactobacillus } \\
\text { acidophilus }\end{array}$ \\
\hline 0 & 4.09 & $8.83 \pm 0.02^{\mathrm{a}}$ \\
20 & 4.07 & $8.69 \pm 0.02^{\mathrm{a}}$ \\
35 & 4.14 & $8.70 \pm 0.02^{\mathrm{a}}$ \\
50 & 4.08 & $8.77 \pm 0.05^{\mathrm{a}}$ \\
65 & 4.11 & $8.78 \pm 0.04^{\mathrm{a}}$ \\
80 & 4.07 & $8.68 \pm 0.04^{\mathrm{a}}$ \\
\hline
\end{tabular}

${ }^{\mathrm{a}}$ Means in the same column followed by the same superscript letter do not differ according to the Tukey test $(P>0.05)$. probiotic yogurts marketed in Brazil (Danone, 2012). Further studies covering functionality tests are needed to verify the behavior and survival of the probiotic cells throughout the gastrointestinal tract.

\section{Rheological Analyses}

Oscillatory Measurements. The mechanical spectrum of the whey-based beverages is shown in Figure 1. The values of $G^{\prime}$ showed little dependence on frequency. The beverage without cheese whey presented higher values of $\mathrm{G}^{\prime}$, and an increasing concentration of cheese whey resulted in decreasing values of $\mathrm{G}^{\prime}$, indicating a less structured beverage. Studies have shown that the addition of whey decreases the strength of the gel, thus increasing the viscous modulus $\left(\mathrm{G}^{\prime \prime}\right)$. According to Gauche et al. (2009), replacing a percentage of cheese whey is a widely used practice in food industry. However, this substitution causes changes in the final product, such as a decrease in viscosity and an increase in syneresis, and a significant decrease in total solids, influencing the formation of a protein network in beverages.

Steady-State Measurements. Figure 2 shows the flow curves. All dairy beverages presented thixotropy and pseudoplastic behavior, as observed by Gauche et al. (2009), who reported that yogurts without whey addition and yogurts with 20 and $30 \%$ (vol/vol) whey also exhibited thixotropic and pseudoplastic behavior. Thixotropy in particulate fragile structures, such as dairy beverages, is irreversible; that is, the network is partially destroyed under shear. The flow curves of the beverage without cheese whey and that with $20 \%$ whey presented overshoot stress, a peak shear stress at low shear rate values (Perrechil et al., 2010). This behavior

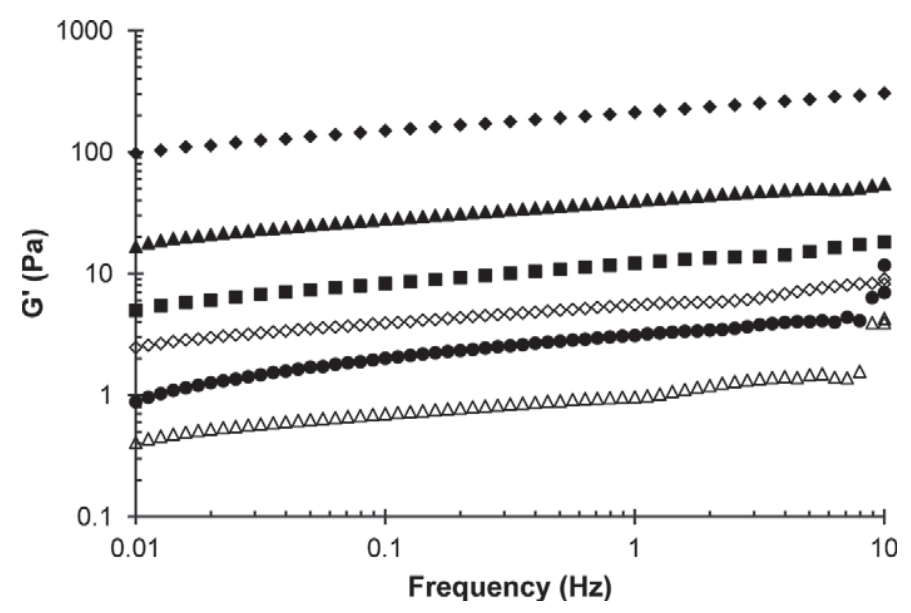

Figure 1. Mechanical spectrum of the whey-based beverages containing (vol/vol) $0 \%(\diamond), 20 \%(\mathbf{\Delta}), 35 \%(\boldsymbol{\square}), 50 \%(\diamond), 65 \%(\bullet)$, and $80 \%(\Delta)$ whey. $\mathrm{G}^{\prime}=$ elastic modulus. 
is associated with more structured and resistant networks (Riscardo et al., 2003) that break with increasing shear rates. The overshoot peaks were $28.325 \pm 9.57 \mathrm{~Pa}$ (no addition of whey) and $19.5 \pm 15.46 \mathrm{~Pa}$ (20\% whey).

Thixotropy can be estimated using the difference between the areas under curves 1 and 2 (Steffe, 1996;
Sato and Cunha, 2007). This measure can be used as a qualitative comparison among different dairy beverages, because the energy required to partially destroy the structure of the food is proportional to the area of hysteresis (Schramm, 1998). The values of thixotropy are shown in Figure 3. According to Figure 3, thixot-
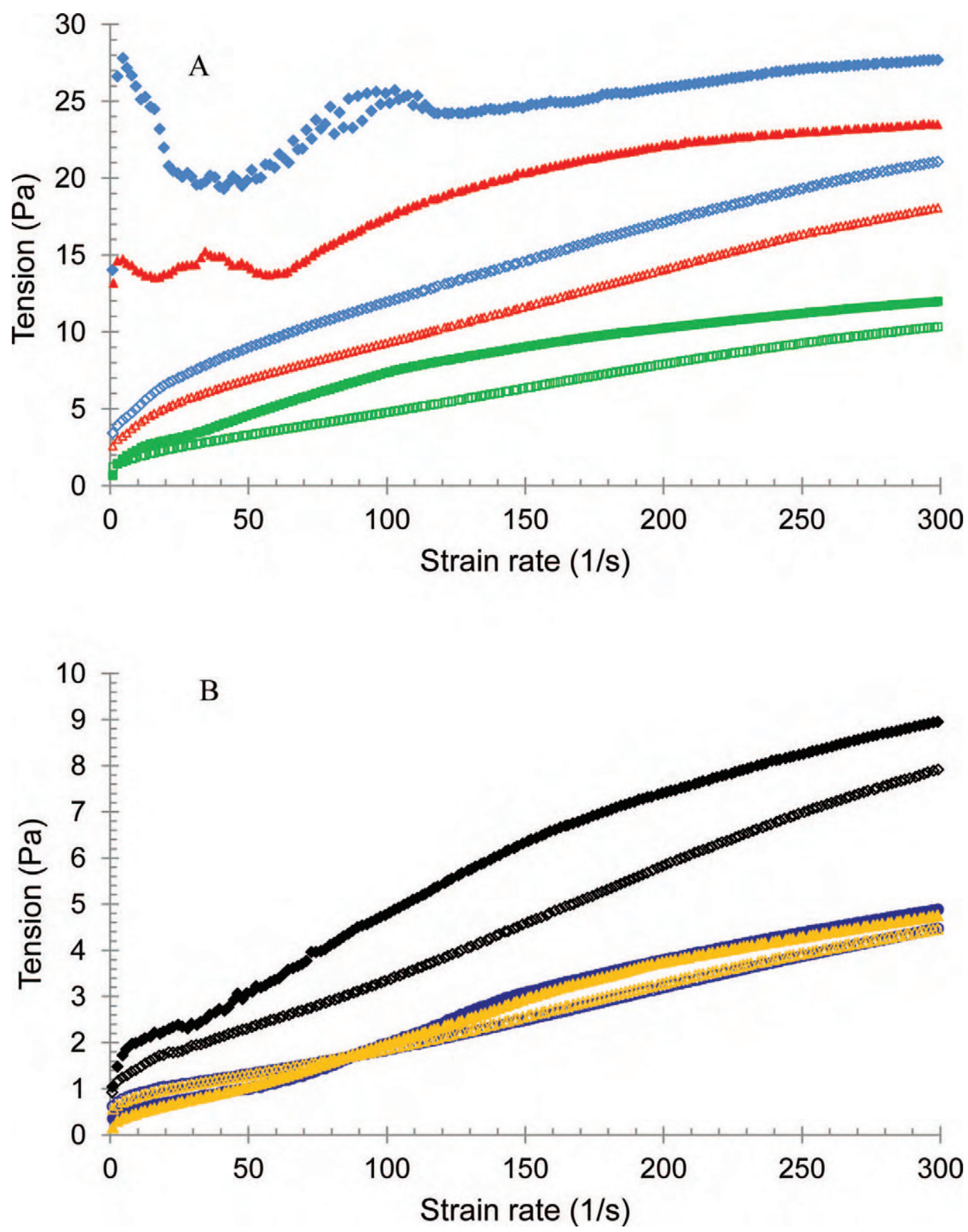

Figure 2. Flow curves of whey-based beverages: (A) low concentrations of whey $(\diamond, \diamond=0 \%, \boldsymbol{\Delta}, \Delta=20 \%, \mathbf{\square}, \square=35 \%$ whey), and (B) high concentrations of whey $(\diamond, \diamond=50 \%, \bullet, \bigcirc=65 \%, \boldsymbol{\Delta}, \Delta=80 \%$ whey). Rising curve $1=$ solid symbols; rising curve $2=$ open symbols. Color version available in the online PDF. 
ropy decreased when the concentration of whey protein increased. The dairy beverage without whey had a thixotropic value of about $3,200 \mathrm{~Pa} \cdot \mathrm{s}^{-1}$, whereas that with $80 \%$ whey protein had a thixotropic value of 31 $\mathrm{Pa} \cdot \mathrm{s}^{-1}$ (almost $1 \%$ of the original value). This decrease in network strength was also observed in the oscillatory assay and can be explained by the decrease in total solids in the formulation with $80 \%$ (wt/wt) whey. Thixotropic materials exhibit decreasing shear stress over time at a fixed rate of shear. In others words, thixotropy is time-dependent thinning. The response of the substance to stress is instantaneous and the timedependent behavior is due to changes in the structure of the material itself. Plotting shear stress versus shear rate for the increasing and decreasing shear rate values can be used to generate a hysteresis loop (a difference in the up and down curves) for the material. The area between the curves depends on the time-dependent nature of the substance. Thixotropy could apply to yogurt: after being manufactured and placed in a container, yogurt slowly develops a 3-dimensional network and may be described as gel. When subjected to shear, the structure is broken down and the materials reach a minimum thickness where they exist in the sol state (Steffe, 1996).

The curves obtained by increasing the shear rate at steady state (rising 2) were mathematically modeled using the power-law equation (Equation [1]) and the results are shown in Table 2 . As seen in Table 2, the beverage without whey presented a more pronounced pseudoplastic behavior: the lowest value of flow index $(n)$ and the highest values of consistency index $(k)$ and viscosity. With the addition of whey, the rheological behavior of beverages changed from pseudoplastic to Newtonian. This trend can be observed by high values of $n$ (close to 1 ) in beverages with more a greater whey content.

\section{Consumer Test}

Table 3 shows the acceptance of the probiotic whey beverages containing different levels of whey. Whey content had an effect on consumer acceptance $(P<$ 0.05): maximum acceptance was observed for the beverage with $35 \%$ whey (mean score of 7.0 on the 9-point hedonic scale). Greater amounts of whey resulted in lower consumer acceptance: samples with 65 and $80 \%$ whey presented mean scores of 5.7 and 5.2 , respectively.

A possible explanation for these results might be the astringency of the beverages with greater amounts of whey. Previous studies reported an increase in astringency of dairy beverages containing greater amounts of whey in their formulation, the $\mathrm{pH}$ of the beverage being one factor indicated as the cause (Lee and Vickers, 2008). Another hypothesis is the interaction resulting from the different charges on the proteins of the saliva (Beecher et al., 2008; Vardhanabhuti et al., 2010), although the extent of this could depend on the $\mathrm{pH}$ of the dairy beverage and on the buffering capacity and flow of saliva. In general, low $\mathrm{pH}$ values and greater flows of saliva attenuate astringency (Kelly et al., 2010). Our results were very interesting, as the acceptance of the

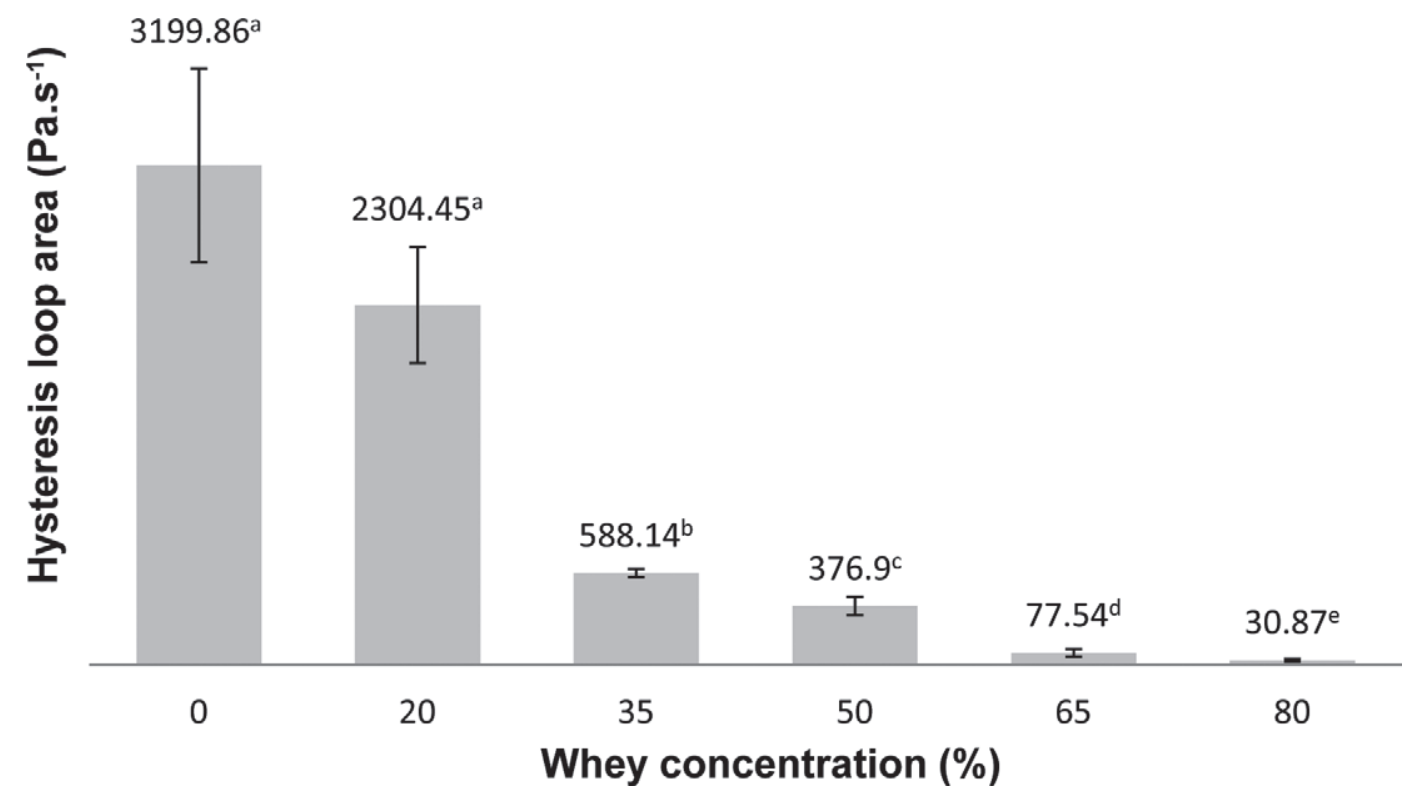

Figure 3. Values of thixotropy (time-dependent change in viscosity, measured by hysteresis loop area) of whey-based beverages. Values followed by different lowercase letters differ according to the Tukey test $(P<0.05)$. 
Table 2. Parameters (means $\pm \mathrm{SD}$ ) estimated by the power-law model for flow curves of probiotic dairy beverages with different whey contents at steady state

\begin{tabular}{|c|c|c|c|c|}
\hline \multirow{2}{*}{$\begin{array}{l}\text { Whey } \\
(\%)\end{array}$} & \multicolumn{4}{|c|}{ Parameter $^{1}$} \\
\hline & $n$ & $k\left(\mathrm{~Pa} \cdot \mathrm{s}^{\mathrm{n}}\right)$ & $\eta\left(100 \mathrm{~s}^{-1}\right)$ & $\mathrm{R}^{2}$ \\
\hline 0 & $0.469 \pm 0.003^{\mathrm{a}}$ & $1.432 \pm 0.040^{\mathrm{a}}$ & $0.119 \pm 0.002^{\mathrm{a}}$ & 0.99 \\
\hline 20 & $0.538 \pm 0.060^{\mathrm{b}}$ & $0.821 \pm 0.030^{\mathrm{b}}$ & $0.093 \pm 0.001^{\mathrm{b}}$ & 0.99 \\
\hline 35 & $0.649 \pm 0.004^{\mathrm{c}}$ & $0.253 \pm 0.006^{\mathrm{c}}$ & $0.048 \pm 0.000^{\mathrm{c}}$ & 0.99 \\
\hline 50 & $0.709 \pm 0.012^{\mathrm{d}}$ & $0.137 \pm 0.015^{\mathrm{d}}$ & $0.034 \pm 0.001^{\mathrm{d}}$ & 0.98 \\
\hline 65 & $0.708 \pm 0.021^{\mathrm{d}}$ & $0.076 \pm 0.010^{\mathrm{e}}$ & $0.018 \pm 0.000^{\mathrm{e}}$ & 0.98 \\
\hline 80 & $0.806 \pm 0.027^{\mathrm{e}}$ & $0.051 \pm 0.008^{\mathrm{f}}$ & $0.019 \pm 0.000^{\mathrm{e}}$ & 0.99 \\
\hline
\end{tabular}

beverages with a high content of whey $(50,65$, and $80 \%)$ did not differ $(P>0.05)$ from that of the control sample (no whey). In regard to using a higher amount of this subproduct, the addition of whey did not influence the acceptance of samples with whey content greater than $50 \%$ over the control sample.

Mean Global Acceptance. To determine whey contents by this method, the solutions for the Equation [5] were determined for $y=6$, which is equivalent to the panelists' opinion "liked slightly." This is the first option within the acceptance region on the hedonic scale and is considered as an index or quality limit (Muñoz et al., 1992).

$$
y=-0.008 x^{2}+0.0611 x+5.3943 .
$$

Thus, the resolution of the second-order polynomial equation resulted in 2 solutions: 12 and $65 \%$ (vol/vol) whey, respectively.

From Table 3, the formulation with $35 \%$ whey had the greatest acceptance and did not differ from the formulation with $20 \%$ whey $(P<0.05)$. Therefore, differences existed between the results obtained by sensorial analysis and those estimated by mathematical models. For example, the solutions of the mean global acceptance equation for acceptance $(\mathrm{y}=6)$ were 12 and $65 \%$ whey. However, the real acceptance score of the sample with $65 \%$ was 5.7 , which explains the difference between real and estimated values, because none of the mathematical models showed the $35 \%$ whey beverage as the sample with the highest sensory acceptance.
Minimal Significant Difference. The calculation of the minimal significant difference shown in Equation [6] resulted in a whey content of $4.26 \%$ $\left(S=5.25-1.96 \sqrt{\frac{2 \times 7.05}{55}}\right)$, confirming the conservative nature of this methodology, because this was the lowest value found for the optimal whey concentration to be added to the probiotic dairy beverage. Similar results were obtained in the optimization of the concentration of hydrolyzed lactose in the manufacture of fudge (Giménez et al., 2008).

Survival Analysis. The survival analysis methodology was used to estimate the maximum concentration of cheese whey, using the results obtained from the consumers when asked if they would normally buy the samples with different concentrations of cheese whey. Because no statistical tests exist to compare the quality of fit of different parametric models used for the interval-censored data, a visual evaluation of the parametric models was used for the nonparametric estimate to choose the most adequate model (Figure 4).

Because the Weibull and LLogistic distributions both presented adequate fits, the Weibull distribution was chosen. The estimates for the maximum likelihood for the Weibull distribution parameters corresponded to $\mu$ $=3.98$ and $\sigma=0.26$. These parameters were used to draw a graph of the percentage rejection by the consumers as a function of the percentage of cheese whey present in the dairy beverage (Figure 5). As shown in Figure 5, we observed a directly proportional relationship between whey concentration and rejection by the

Table 3. Average consumer acceptance of dairy beverages with different whey contents

\begin{tabular}{lcccccc}
\hline & \multicolumn{5}{c}{ Whey $(\%)$} \\
\cline { 2 - 6 } Item & 0 & 20 & 35 & 50 & 65 & 80 \\
\hline Acceptance $^{1}$ & $5.2^{\mathrm{c}}$ & $6.4^{\mathrm{ab}}$ & $7.0^{\mathrm{a}}$ & $5.9^{\mathrm{bc}}$ & $5.7^{\mathrm{bc}}$ & $5.2^{\mathrm{c}}$ \\
\hline${ }^{{ }^{\mathrm{a}} \mathrm{c} \text { Values followed by different superscript letters differ according to the Tukey test }(P<0.05) .}$ \\
${ }^{1}$ Evaluated on a 9-point hybrid hedonic scale from $1=$ disliked extremely to $9=$ liked extremely.
\end{tabular}



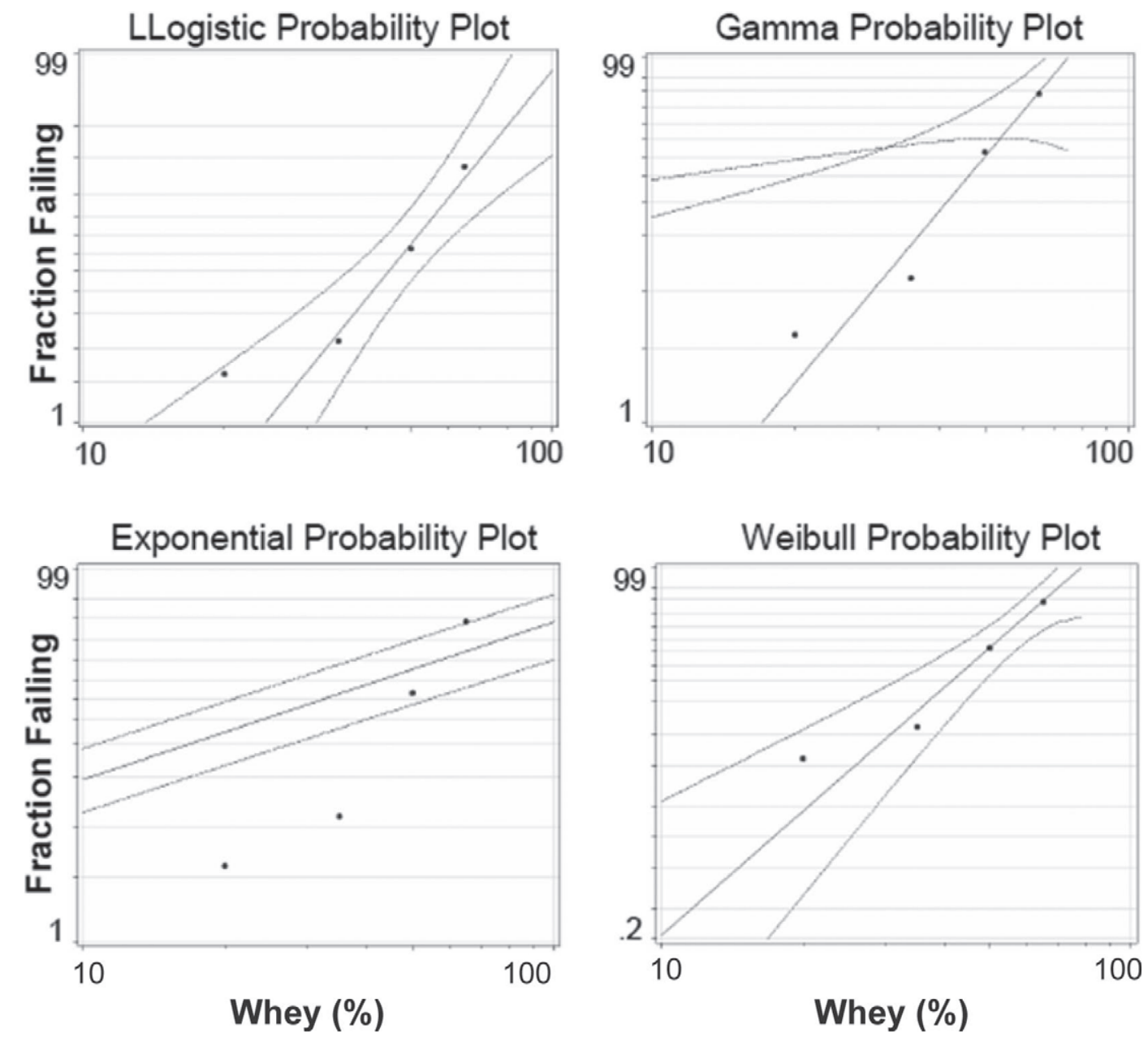

Figure 4. The probability of consumers rejecting (fraction failing) the probiotic dairy beverages with different percentages of whey according to 4 distribution models (LLogistic, Gamma, Exponential, and Weibull).

consumer, with respect to buying the beverages, confirming the results of the consumer test.

Previous studies reported the use of survival analysis in development of dairy products. Cruz et al. (2010) used survival analysis to estimate the shelf life of probiotic yogurts. Those authors found that shelf life was 38 and $53 \mathrm{~d}$ for probabilities of consumer rejection of 25 and $50 \%$, respectively, by Weibull distribution model. Giménez et al. (2008) measured the change in sensory acceptance of dulce de leche depending on the level of lactose hydrolyzed. The survival analysis and minimum significant difference models showed similar results to estimate the concentration of lactose hydrolyzed in dulce de leche.

Considering 25 and $50 \%$ rejection by the consumers, the survival analysis indicated values of $40 \%$ and $49 \%$ whey in the formulations, respectively. Nevertheless, considering the elevated nutritional quality of the whey, the need to reduce the costs of the formulation, and the need to minimize the emission of polluting

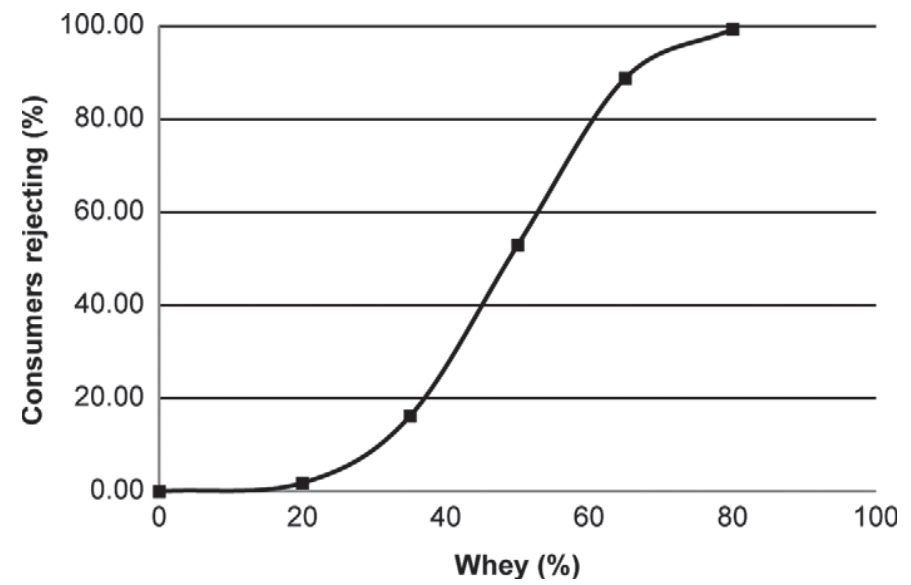

Figure 5. Percentage of consumers rejecting the probiotic dairy beverages with different percentages of whey, according to the Weibull distribution. 
substances, the use of cheese whey meets the needs of the food industry. An analysis of the results presented by the different mathematical methodologies allowed for the selection of 2 probiotic beverage formulations: the first, determined by the survival analysis, contained $49 \%$ cheese whey in its formulation, and the second, determined by the mean global acceptance, contained $65 \%$ whey. Thus, we attempted to reconcile the reaction of consumers when exposed to these products (a determinant factor in the first acquisition of a product) and consumer loyalty to the brand, while meeting current demands of the dairy industry.

Future studies should include the use of descriptive sensory tests to determine the sensory profile of the lactic beverages compared with similar commercial products, and to adopt methodologies to verify consumer perception of these products.

\section{CONCLUSIONS}

Increasing the level of cheese whey caused a decrease in hysteresis area; however, no significant difference was observed in the hysteresis of the samples with 0 and $20 \%$ whey. Replacement of casein by whey protein caused a reduction in gel strength. The mathematical methodologies used to develop the probiotic whey beverages were adequate, and the differences found were caused by intrinsic characteristics of the methods in obtaining results. The principal aim was to maximize the use of the industrial by-product cheese whey while meeting the demands of consumers. Probiotic dairy beverages could be produced with $49 \%$ (obtained by the survival analysis methodology) and $65 \%$ (obtained by the mean global acceptance methodology) cheese whey, respectively. It is possible to increase the whey content in probiotic dairy beverages without negatively affecting functionality and acceptability, thus making better use of this by-product.

\section{ACKNOWLEDGMENTS}

The authors are grateful to CAPES, FAEPEX/UNICAMP for a doctoral scholarship and financing of the research, to Duas Rodas (Jaraguá do Sul, Brazil) and Dölher (Limeira, Brazil) for providing and preparing the fruits, and to DuPont (Copenhagen, Denmark) for the microbial cultures used.

\section{REFERENCES}

Almeida, K. E., A. Y. Tamine, and M. N. Oliveira. 2008. Acidification rates of probiotic bacteria in Minas Frescal cheese whey. Lebenson. Wiss. Technol. 41:311-316.

Almeida, K. E., A. Y. Tamine, and M. N. Oliveira. 2009. Influence of total solids contents of milk whey on the acidifying profile and viability of various lactic acid bacteria. Lebenson. Wiss. Technol. $42: 672-678$.

Araneda, M., G. Hough, and E. W. De Penna. 2008. Current status survival analysis methodology to estimating sensory shelf life of ready-to-eat lettuce (Lactuca sativa). J. Sens. Stud. 23:162-170.

Ares, G., R. Baixauli, T. Sanz, P. Varela, and A. Salvador. 2009. New functional fibre in milk puddings: Effect on sensory properties and consumers' acceptability. Lebenson. Wiss. Technol. 42:710-716.

Beecher, J. W., M. A. Drake, P. J. Luck, and E. A. Foegeding. 2008. Factors regulating astringency of whey protein beverages. J. Dairy Sci. 91:2553-2560.

Brazil. 2003. Regulamento Técnico de Porções de alimentos embalados para fins de rotulagem nutricional. Accessed Jul. 15, 2012. http:// www.anvisa.gov.br/alimentos/rotulos/resolucoes.htm.

Brazil. 2005. Ministério da Agricultura, Pecuária e Abastecimento. Legislação. SISLEGIS: Sistema de Consulta à Legislação. Instrução Normativa no. 16, de 23 de agosto de 2005. (Technical rules of identity and quality whey-based drinks.) Accessed Aug. 28, 2012. http://extranet.agricultura.gov.br/sislegis-consulta/ consultarLegislacao.do operacao $=$ visualizar\&id $=12792$.

Brazil. 2008. Alimentos com Alegações de Propriedades Funcionais e ou de Saúde, Novos Alimentos/Ingredientes, Substâncias Bioativas e Probióticos: Lista de alegações de propriedade funcional aprovadas (Atualizado em julho/2008). Accessed Jul. 15, 2012. http://www.anvisa.gov.br/alimentos/comissoes/tecno_lista_alega. htm.

Brazil. 2012. Ministério de Desenvolvimento, Indústria e Comércio Exterior. ALICE: Sistema de Análise das Informações de Comércio Exterior. [System for Analysis of Foreign Trade Information via Internet (ALICEWEB)]. Accessed May 22, 2012. http://www. milkpoint.com.br/estatisticas/exportacoes_brasileiras.htm.

Castro, F. P., T. M. Cunha, P. J. Ogliari, R. F. Teófilo, M. M. C. Ferreira, and E. S. Prudêncio. 2009. Influence of different content of cheese whey and oligofructose on the properties of fermented lactic beverages: Study using response surface methodology. Lebenson. Wiss. Technol. 42:993-997.

Cruz, A. G., W. F. Castro, J. A. F. Faria, P. C. B. Lollo, J. AmayaFarfán, M. Q. Freitas, D. Rodrigues, C. A. F. Oliveira, and H. T. Godoy. 2012. Probiotic yogurts manufactured with increased glucose oxidase levels: Post acidification, proteolytic patterns, survival of probiotic microorganisms, production of organic and aroma compounds. J. Dairy Sci. 95:2261-2269.

Cruz, A. G., E. H. M. Walter, R. S. Cadena, J. A. F. Faria, H. M. A. Bolini, H. P. Pinheiro, and A. S. Sant'Ana. 2010. Survival analysis methodology to predict the shelf-life of probiotic flavored yogurt. Food Res. Int. 43:1444-1448.

Danone. 2012. Actimel e Activia: Conheça nossos produtos. Accessed Jul. 15, 2012. http://www.danone.com.br/nossasmarcas.php.

Debon, J., E. S. Prudêncio, and J. C. C. Petrus. 2010. Rheological and physico-chemical characterization of prebiotic microfiltered fermented milk. J. Food Eng. 99:128-135.

Debon, J., E. S. Prudêncio, J. C. C. Petrus, C. B. Fritzen-Freire, C. M. O. Müller, R. D. de M. C. Amboni, and C. R. W. Vieira. 2012. Storage stability of prebiotic fermented milk obtained from permeate resulting of the microfiltration process. Lebenson. Wiss. Technol. 47:96-102.

Di Criscio, T., A. Fratianni, R. Mignogna, L. Cinquanta, R. Coppola, E. Sorrentino, and G. Panfili. 2010. Production of functional probiotic, prebiotic, and synbiotic ice creams. J. Dairy Sci. 93:45554564 .

Drake, M. A. 2007. Invited review: Sensory analysis of dairy foods. J. Dairy Sci. 90:4925-4937.

Escobar, M. C., M. L. Van Tassell, F. Martínez-Bustos, M. Singh, E. Castaño-Tostado, S. L. Amaya-Llano, and M. J. Miller. 2012. Characterization of a Panela cheese with added probiotics and fava bean starch. J. Dairy Sci. 95:2779-2787.

Ferraz, J. L., A. G. Cruz, R. S. Cadena, M. Q. Freitas, U. M. Pinto, C. C. Carvalho, J. A. F. Faria, and H. M. A. Bolini. 2012. Sensory acceptance and survival of probiotic bacteria in ice cream produced with different overrun levels. J. Food Sci. 77:S24-S28. 
Fluegel, S. M., T. D. Shultz, J. R. Powers, S. Clark, C. BarbosaLeiker, B. R. Wright, T. S. Freson, H. A. Fluegel, J. D. Minch, L. K. Schwarzkopf, A. J. Miller, and M. M. Di Filippo. 2010. Whey beverages decrease blood pressure in prehypertensive and hypertensive young men and women. Int. Dairy J. 20:753-760.

Gámbaro, A., A. Giménez, P. Varela, L. Garitta, and G. Hough. 2004. Sensory shelf-life estimation of alfajor by survival analysis. J. Sens. Stud. 19:500-509.

Gauche, C., T. Tomazi, P. L. M. Barreto, P. J. Ogliari, and M. T. Bordignon-Luiz. 2009. Physical properties of yoghurt manufactured with milk whey and transglutaminase. Lebenson. Wiss. Technol. 42:239-243.

Giménez, A., G. Ares, and A. Gámbaro. 2008. Consumer reaction to changes in sensory profile of dulce de leche due to lactose hydrolysis. Int. Dairy J. 18:951-955.

Gomes, A. A., S. P. Braga, A. G. Cruz, R. S. Cadena, P. C. B. Lollo, C. Carvalho, J. Amaya-Farfán, J. A. F. Faria, and H. M. A. Bolini. 2011. Effect of the inoculation level of Lactobacillus acidophilus in probiotic cheese on the physicochemical features and sensory performance compared with commercial cheeses. J. Dairy Sci. 94:4777-4786.

Granato, D., G. F. Branco, A. G. Cruz, J. A. F. Faria, and N. P. Shah. 2010. Probiotic dairy products as functional foods. Comp. Rev. Food Sci. Food Saf. 9:455-470.

Hassan, A. N., J. F. Frank, K. A. Schimidt, and S. I. Shalabi. 1996. Rheological properties of yogurt made with encapsulated nonropy lactic cultures. J. Dairy Sci. 79:2091-2097.

Hough, G., M. L. Calle, C. Serrat, and A. Curia. 2007. Number of consumers necessary for shelf life estimations based on survival analysis statistics. Food Qual. Prefer. 18:771-775.

Hough, G., and L. Garitta. 2012. Methodology for sensory shelf-life estimation: A review. J. Sens. Stud. 27:137-147.

Hough, G., K. Langohr, G. Gomez, and A. Curia. 2003. Survival analysis applied to sensory shelf life of foods. J. Food Sci. 68:359-362.

Hough, G., M. L. Puglieso, R. Sánchez, and O. M. Silva. 1999. Sensory and microbiological shelf-life of a commercial Ricotta cheese. J. Dairy Sci. 82:454-459.

Hough, G., R. H. Sánchez, G. Garbarini de Pablo, R. G. Sánchez, S. Calderón Villaplana, A. M. Giménez, and A. Gámbaro. 2002. Consumer acceptability versus trained sensory panel scores of powdered milk shelf-life defects. J. Dairy Sci. 85:2075-2080.

Jacobo-Velázquez, D. A., P. A. Ramos-Parra, and C. HernándezBrenes. 2010. Survival analysis applied to the sensory shelf-life dating of high hydrostatic pressure processed avocado and mango pulps. J. Food Sci. 75:S286-S291.

Kelly, M. A., B. Vardhanabhuti, P. J. Luck, M. A. Drake, J. Osborne, and E. A. Foegeding. 2010. Role of protein concentration and protein-saliva interactions in the astringency of whey proteins at low pH. J. Dairy Sci. 93:1900-1909.

Krešić, G., Z. Herceg, V. Lelas, and A. R. Jambrak. 2010. Consumers behaviour and motives for selection of dairy beverages in Kvarner region: A pilot study. Mljekarstvo 60:50-58.

Lee, C. A., and Z. M. Vickers. 2008. The astringency of whey protein beverages is caused by their acidity. Int. Dairy J. 18:1153-1156.

MacFie, H. J., N. Bratchell, K. Greenhoff, and L. V. Vallis. 1989. Designs to balance the effect of order of presentation and first-order carry-over effects in hall tests. J. Sens. Stud. 4:129-148.

Madureira, A. R., M. S. Gião, M. E. Pintado, A. M. P. Gomes, A. C. Freitas, and F. X. Malcata. 2005. Incorporation and survival of probiotic bacteria in whey cheese matrices. J. Food Sci. 70:160165.

Madureira, A. R., C. I. Pereira, A. M. P. Gomes, M. E. Pintado, and F. X. Malcata. 2007. Bovine whey proteins-Overview on their main biological properties. Food Res. Int. 40:1197-1211.

Madureira, A. R., A. I. Pintado, A. M. P. Gomes, M. E. Pintado, and F. X. Malcata. 2011a. Rheological, textural and microstruc- tural features of probiotic whey cheeses. Lebenson. Wiss. Technol. $44: 75-81$.

Madureira, A. R., J. C. Soares, A. C. Freitas, M. E. Pintado, A. M. P. Gomes, and F. X. Malcata. 2011b. Sweet whey cheese matrices inoculated with the probiotic strain Lactobacillus paracase LAFTI $^{\text {in }}$ L26. J. Dairy Sci. Technol. 89:649-655.

Madureira, A. R., J. C. Soares, A. M. P. Gomes, M. E. Pintado, A. C. Freitas, and F. X. Malcata. 2008. Sweet whey cheese matrices inoculated with Lactobacillus paracasei. Lait 88:649-665.

Madureira, A. R., T. Tavares, A. M. P. Gomes, M. E. Pintado, and F. X. Malcata. 2010. Invited review: Physiological properties of bioactive peptides obtained from whey proteins. J. Dairy Sci. 93:437-455.

Marafon, A. P., A. Sumi, M. R. Alcântara, A. Y. Tamine, and M. N. Oliveira. 2011. Optimization of the rheological properties of probiotic yoghurts supplemented with milk proteins. Lebenson. Wiss. Technol. 44:511-519.

Marshall, R. T. 1993. Standard Methods for Examination of Dairy Products. American Public Health Association, Washington, DC.

Mortazavian, A. M., M. R. Ehsani, S. M. Mousavi, K. Rezaei, S. Sohrabvandi, and J. A. Reinheimer. 2007. Effect of refrigerated storage temperature on the viability of probiotic micro-organisms in yogurt. Int. J. Dairy Technol. 60:123-127.

Muñoz, A. M., V. G. Civille, and B. T. Carr. 1992. Sensory Evaluation in Quality Control. Van Nostrand Reinhold, New York, NY.

Nielsen, V. 1975. Factors which control the body and texture of commercial yoghurts. Am. Dairy Rev. 37:36-38

Oliveira, M. N., I. Sodini, F. Remeuf, J. P. Tissier, and G. Corrieu. 2002. Manufacture of fermented lactic beverages containing probiotic cultures. J. Food Sci. 67:2336-2341.

Parnell-Clunies, E., Y. Kakuda, and J. Deman. 1986. Influence of heat treatment of milk on the flow properties of yogurt. J. Food Sci. 51:1459-1462.

Perrechil, F. A., R. C. Santana, L. H. Fasolin, C. A. S. Silva, and R. L. Cunha. 2010. Rheological and structural evaluations of commercial Italian salad dressing. Ciên. Tecnol. Alim. 30:477-482.

Pinto, S. S., C. B. Fritzen-Freire, I. B. Muñoz, P. L. M. Barreto, E. S. Prudêncio, and R. D. M. C. Amboni. 2012. Effects of the addition of microencapsulated Bifidobacterium BB-12 on the properties of frozen yogurt. J. Food Eng. 111:563-569.

Ranadheera, R. D. C. S., S. K. Baines, and M. C. Adams. 2010. Review: Importance of food in probiotic efficacy. Food Res. Int $43: 1-7$.

Riscardo, M. A., J. M. Franco, and C. Gallegos. 2003. Influence of composition of emulsifier blends on the rheological properties of salad dressing-type emulsions. Food Sci. Technol. Int. 9:53-63.

Sato, A. C. K., and R. L. Cunha. 2007. Influence of temperature on the rheological behavior of jabuticaba pulp. Ciênc. Technol. Alim. $27: 890-896$.

Schramm, G. 1998. Reologia: Podstawy i zastosowania [Rheology: Fundamentals and Practice]. Osrodek Wydawnictw Nawkowygh Pan Poznán, Poznán, Poland. (in Polish)

Steffe, J. F. 1996. Rheological Methods in Food Process Engineering. 2nd ed. Freeman Press, East Lansing. MI.

Vardhanabhuti, B., M. A. Kelly, P. J. Luck, M. A. Drake, and E. A. Foegeding. 2010. Roles of charge interactions on astringency of whey proteins at low pH. J. Dairy Sci. 93:1890-1899.

Zhu, K., Z. Fan, C. Xu, and L. Jia. 2009. Studies on impact of health factors on yogurt consumption behaviors of Beijing consumers. J. Chin. Inst. Food Sci. Technol. 9:185-188.

Zoellner, S. S., A. G. Cruz, J. A. F. Faria, H. M. A. Bolini, M. R. L. Moura, L. M. J. Carvalho, and A. S. Sant'ana. 2009. Whey beverage with acai pulp as a food carrier of probiotic bacteria. Aust. J. Dairy Technol. 64:165-169. 